\title{
Efficacy of Herbicides ApPlied to Digitaria horizontalis Plants UNDER DIFFERENT WATER CONDITIONS ${ }^{1}$
}

\author{
Eficácia de Herbicidas Aplicados em Plantas de Digitaria horizontalis Submetidas a Diferentes \\ Condições Hídricas
}

\author{
PEREIRA, M.R.R. ${ }^{2}$, MARTINS, D. ${ }^{3}$, SOUZA, G.S.F. ${ }^{4}$, RODRIGUES-COSTA, A.C.P. ${ }^{5}$ e \\ KLAR, A.E. ${ }^{6}$
}

\begin{abstract}
This project aimed to relate the control efficiency of ACCase inhibiting herbicides applied post-emergence to Digitaria horizontalis plants under different soil water contents. The experiments were conducted in a greenhouse, with the application of three different herbicides (fluazifop-p-butyl, haloxyfop-methyl, and sethoxydim + mineral oil Assist). The experimental design used for each herbicide was completely randomized, with four replications, consisting of a $3 \times 4$ factorial, with the combination of water management strategies $(-0.03$, -0.07 and $-1.5 \mathrm{MPa}$ ) and four doses of these products $(100 \%, 50 \%, 25 \%$, and $0 \%$ of the recommended dose). Herbicide application was made at two vegetative stages, 4-6 leaves and 2-3 tillers. The visual phytotoxicity evaluations were performed at 14 days after application and the plant dry weight at the end of the study was evaluated. The control efficiency was not affected by water management strategies when applied to the recommended dose of the herbicides in early stages of plant development (4-6 leaf stage). In late applications (2-3 tiller stage) the plants held under drought stress showed less phytotoxicity.
\end{abstract}

Keywords: crabgrass, chemical control, water restriction, weed.

RESUMO - Este projeto objetivou relacionar a eficiencia de controle de herbicidas inibidores da ACCase aplicados em pós-emergência em plantas de Digitaria horizontalis submetidas a diferentes teores de água no solo. Os experimentos foram conduzidos em casa de vegetação, com a aplicação de três diferentes herbicidas (fluazifop-p-butil, haloxyfop-methyl e sethoxydim + óleo mineral Assist). $O$ delineamento experimental utilizado para cada herbicida foi inteiramente casualizado, com quatro repetições, constituído de um fatorial $3 \times 4$, sendo a combinação de três manejos hídricos (-0,03, 0,07 e -1,5 MPa) e quatro doses desses produtos (100, 50, 25 e 0\% da dose recomendada). A aplicação dos herbicidas foi feita em dois estádios vegetativos: 4-6 folhas e 2-3 perfilhos. As avaliações visuais de fitotoxicidade foram realizadas aos 14 dias após a aplicação e avaliou-se a matéria seca das plantas ao final do estudo. A eficiência de controle não foi influenciada pelos manejos hídricos quando se aplicou a dose recomendada de todos os herbicidas na fase inicial de desenvolvimento das plantas (estádio de 4-6 folhas). Em aplicações tardias (estádio de 2-3 perfilhos), as plantas mantidas sob estresse hidrico apresentaram menor fitotoxicidade.

Palavras-chave: capim-colchão, controle químico, restrição hídrica, planta daninha.

1 Recebido para publicação em 5.4.2011 e aprovado em 9.8.2011.

2 Doutora em Agronomia, Pós-Doutoranda, Faculdade de Ciências Agronômicas, Universidade Estadual Paulista “Júlio de Mesquita Filho” - FCA/UNESP, Caixa Postal 237, 18603-970 Botucatu-SP, <mariarenata10@hotmail.com>; ${ }^{3}$ Professor Adjunto, Dep. de Produção Vegetal, FCA/UNESP, Botucatu-SP; ${ }^{4}$ Engo-Agro ., MSc., Doutorando, FCA/UNESP, Botucatu-SP, ${ }^{5}$ Pós-Doutoranda, Universidade Estadual do Oeste do Paraná - UEOP, Caixa Postal 1008, Marechal Cândido Rondon-PR; ${ }^{6}$ Professor Titular, Dep. de Engenharia Rural, FCA/UNESP, Botucatu-SP. 


\section{INTRODUCTION}

Weeds affect crop development and this interference is influenced by factors related to cultivation, such as species or variety, spacing and planting density, sowing timing and the extension of the period of coexistence between the crop and the weeds, and also by the own characteristic factors of the weeds, such as specified composition, density, and distribution (Pitelli, 1985), besides the allelopathic effects provided by these weeds to the crops (Muniz et al., 2007; Borghi et al., 2008; Tejeda-Sartorius \& Rodríguez-González, 2008).

Currently, the use of herbicides is an essential and common practice in agricultural areas because of the extensive farming and the high cost of labor (Vieira, 2010). The effectiveness of a herbicide depends on several factors, such as physical and chemical characteristics and the applied dose, the species to be controlled (own structural characteristics), the development stage and the biology features of the weed, application techniques, the soil moisture, and environmental factors at the time of herbicide application - i.e. temperature, air humidity, rainfall, solar radiation, and wind (Victoria Filho, 1985).

According to the studies of Zannata et al. (2008) the effectiveness of herbicides is reduced when applied to plants developed under conditions of water deficit due to low absorption and translocation of the product. Prolonged periods of drought can cause leaf thickening, increased density of the cuticle, and greater leaf pubescence, as well as tissue dehydration, disturbing the diffusion (Kogan \& Bayer, 1996) and leading to reduced absorption and translocation of herbicides.

The control of Digitaria sanguinalis with $30 \mathrm{~g} \mathrm{ha}^{-1}$ of haloxyfop-methyl was of $92 \%$ for non-stressed plants and $8 \%$ for those in water stress (Peregoy et al., 1990). According to Levene \& Owen (1995), plants in water stress (Xanthiumstrumarium and Abutilon theophrasti) showed more vertically oriented leaves than non-stressed plants. This fact could potentially reduce exposure of the leaf area and, consequently, decrease the retention of the droplet. Corroborating these results, Pereira et al. (2010) found that Urochloa plantaginea plants under water stress were not effectively controlled by herbicides that inhibit ACCase when applied during late stage.

The aim of this study was to compare the control efficiency of ACCase inhibiting herbicides applied post-emergence to Digitaria horizontalis plants when subjected to water stress, determining the soil water potential which could impair the efficiency of these herbicides.

\section{MATERIAL AND METHODS}

The studies were carried out from January to March 2009 with the following characterization of the climate during this period in the greenhouse (average): Minimum average temperature of $20.3^{\circ} \mathrm{C}$, maximum average temperature of $29{ }^{\circ} \mathrm{C}$, air humidity at $76.1 \%$, and evapotranspiration of $3.07 \mathrm{mmonth}^{-1}$, which was daily monitored through a Class A Tank.

The species used was $D$. horizontalis, grown in plastic pots with $2 \mathrm{~L}$, maintained in a greenhouse. The description of soil texture was classified as average through the sieve analysis (65.6\% sand, silt $6.7,27.7$ clay). Soil fertilization was performed according to chemical analysis (Table 1).

The soil, before planting, was dried in air, turned over twice a week until constant weight. Richards' pressure plate was used to obtain the water retention curve (Klar, 1984).

Table 1 - Chemical analysis of soil used in the study. Botucatu-SP, 2009/2008

\begin{tabular}{|c|c|c|c|c|c|c|c|c|c|}
\hline $\mathrm{pH}$ & $\mathrm{MO}$ & $\mathrm{P} \mathrm{resin}$ & $\mathrm{H}+\mathrm{Al}$ & $\mathrm{K}$ & $\mathrm{Ca}$ & $\mathrm{Mg}$ & $\mathrm{SB}$ & $\mathrm{CTC}$ & $\mathrm{V}$ \\
\hline$\left(\mathrm{CaCl}_{2}\right)$ & $\left(\mathrm{g} \mathrm{dm}^{-3}\right)$ & $\left(\mathrm{mg} \mathrm{dm}^{-3}\right)$ & \multicolumn{5}{|c|}{$\left(\mathrm{mmol} \mathrm{dm}^{-3}\right)$} & & $(\%)$ \\
\hline 4.6 & 7 & 3 & 22 & 0.2 & 2 & 2 & 4 & 26 & 15 \\
\hline
\end{tabular}


From the results of water retention, three minimum water potentials were established ( $\Psi \mathrm{s})$ : -0.03, -0.07, and -1.5 MPa, with 13, 10, and $8 \%$ soil moisture, respectively, compounding the water management, evaluated by pots weighing. Upon reaching the approximation of the potential defined for each treatment, the transpired water replacement was done until reaching mass of maximum water potential of soil water retention $(-0.01 \mathrm{MPa} / 14 \%$ soil moisture). The water management strategies were initiated in the development stage of two leaves on each plant.

A backpack sprayer was used, equipped with application bar containing four spray nozzles of plan type XR11002VS, with a solution consumption of $200 \mathrm{~L} \mathrm{ha}^{-1}$.

Herbicide application was performed during weed development (4-6 leaves and 2-3 tillers). Three different herbicides were applied (fluazifop-p-butyl, haloxyfop-methyl, and sethoxydim + mineral oil Assist) and the experimental design used for each product was completely randomized, with four replications, consisting of a $3 \times 4$ factorial, with the combination of three water managements $(-0.03,-0.07$, and $-1.5 \mathrm{MPa})$ and four doses of these products $(100,50,25$, and $0 \%$ of the recommended dose). According to the manufacturers of each product, $100 \%$ of recommended dose of each herbicide in grams of active ingredient per hectare is $\left(\mathrm{g}\right.$ a.i. $\left.\mathrm{ha}^{-1}\right)$ : sethoxydim, 184; haloxyfop-methyl, 60; and fluazifop-p-butyl, 125.

The effects of chemical treatments on the plants were visually evaluated 14 days after application through a percentage score scale in which "0" indicates no control and "100" indicates the plant's death (SBCPD, 1995). At the end of the evaluations, the plants were dried in forced ventilation of air at $60{ }^{\circ} \mathrm{C}$ until constant weight and then the dry mass of the samples were determined.

The experimental design used in the studies was completely randomized with four replications. The results of phytotoxicity were subjected to analysis of variance by "F-test ", and the dry plant mass to linear regression models and polynomial, with the treatment averages compared by Tukey test at $5 \%$ probability.

\section{RESULTS AND DISCUSSION}

At 14 DAA, when applying $100 \%$ of the recommended dose of different herbicides on plants at 4-6 leaf stage, it was observed that all of them were effective in weed control of crabgrass, regardless of water management strategy, which shows that the full doses of these herbicides are not influenced by the efficiency levels of water stress (Tables 2, 3, and 4).

Neither there was a decrease of the control percentages when the dose of the herbicides was reduced by $50 \%$, compared to the full dose applications, in plants grown in soil with minimum stresses of -0.03 and $-0.07 \mathrm{MPa}$ soil water. In plants under severe water

Table 2 - Percentage of control plants of $D$. horizontalis at the stage of 4-6 leaves subjected to different managements water, 14 days after application of the herbicide fluazifop-p-butil. Botucatu-SP, 2008/2009

\begin{tabular}{|c|c|c|c|c|}
\hline \multirow{2}{*}{$\begin{array}{c}\text { Water management } \\
(\mathrm{MPa})\end{array}$} & \multicolumn{4}{|c|}{ Percentage of the dose of herbicide } \\
\hline & 0 & 25 & 50 & 100 \\
\hline-0.03 & $0.00 \mathrm{aC}$ & $57.50 \mathrm{aB}$ & $99.75 \mathrm{aA}$ & $100.00 \mathrm{aA}$ \\
\hline-0.07 & $0.00 \mathrm{aC}$ & $58.75 \mathrm{aB}$ & $97.75 \mathrm{aA}$ & $100.00 \mathrm{aA}$ \\
\hline-1.5 & $0.00 \mathrm{aD}$ & $57.50 \mathrm{aC}$ & $65.00 \mathrm{bB}$ & $100.00 \mathrm{aA}$ \\
\hline $\mathrm{F}$ Water Management $(\mathrm{W})$ & \multicolumn{4}{|c|}{$29.414 * *$} \\
\hline$F_{\text {dose }}(\mathrm{D})$ & \multicolumn{4}{|c|}{$1777.644^{* *}$} \\
\hline$F(W) \times(D)$ & \multicolumn{4}{|c|}{$28.138 * *$} \\
\hline CV (\%) & \multicolumn{4}{|c|}{6.0} \\
\hline
\end{tabular}

Means followed by same letter in the column and capital on the line, do not differ by Tukey test $(\mathrm{p}>0.05) .{ }^{* *}$ significant value for the test " $\mathrm{F}$ " $(\mathrm{p} \leq 0.01)$.

Table 3 - Percentage of control plants of $D$. horizontalis at the stage of 4-6 leaves subjected to different managements water, 14 days after application of the herbicide haloxyfop-methyl. Botucatu-SP, 2008/2009

\begin{tabular}{|c|c|c|c|c|}
\hline \multirow{2}{*}{$\begin{array}{c}\text { Water management } \\
(\mathrm{MPa})\end{array}$} & \multicolumn{4}{|c|}{ Percentage of the dose of herbicide } \\
\cline { 2 - 5 } & 0 & 25 & 50 & 100 \\
\hline-0.03 & $0.00 \mathrm{aC}$ & $58.75 \mathrm{aB}$ & $97.50 \mathrm{aA}$ & $100.00 \mathrm{aA}$ \\
\hline-0.07 & $0.00 \mathrm{aC}$ & $52.50 \mathrm{aB}$ & $95.00 \mathrm{aA}$ & $100.00 \mathrm{aA}$ \\
\hline-1.5 & $0.00 \mathrm{aD}$ & $23.75 \mathrm{bC}$ & $88.25 \mathrm{aB}$ & $98.75 \mathrm{aA}$ \\
\hline $\mathrm{F}_{\text {Water Management }}(\mathrm{W})$ & \multicolumn{4}{|c}{$19.928^{* *}$} \\
\hline $\mathrm{F}_{\text {dose }}(\mathrm{D})$ & \multicolumn{4}{|c}{$891.465^{* *}$} \\
\hline $\mathrm{F}(\mathrm{W}) \times(\mathrm{D})$ & $10.308^{* *}$ \\
\hline $\mathrm{CV}(\%)$ & \multicolumn{4}{|c}{9.1} \\
\hline
\end{tabular}

Means followed by same letter in the column and capital on the line, do not differ by Tukey test $(\mathrm{p}>0.05)$. ${ }^{* *}$ significant value for the test "F" ( $\mathrm{p} \leq 0.01)$.

Planta Daninha, Viçosa-MG, v. 30, n. 1, p. 165-172, 2012 
Table 4 - Percentage of control plants of $D$. horizontalis at the stage of 4-6 leaves subjected to different managements water, 14 days after application of the herbicide sethoxydim. Botucatu-SP, 2008/2009

\begin{tabular}{|c|c|c|c|c|}
\hline \multirow{2}{*}{$\begin{array}{c}\text { Water management } \\
(\mathrm{MPa})\end{array}$} & \multicolumn{4}{|c|}{ Percentage of the dose of herbicide } \\
\hline & 0 & 25 & 50 & 100 \\
\hline-0.03 & $0.00 \mathrm{aC}$ & $94.50 \mathrm{aB}$ & $98.25 \mathrm{aAB}$ & $100.00 \mathrm{aA}$ \\
\hline-0.07 & $0.00 \mathrm{aC}$ & $42.50 \mathrm{bB}$ & $96.50 \mathrm{abA}$ & $100.00 \mathrm{aA}$ \\
\hline-1.5 & $0.00 \mathrm{aC}$ & $92.00 \mathrm{aB}$ & $92.50 \mathrm{bB}$ & $96.75 \mathrm{aA}$ \\
\hline $\mathrm{F}_{\text {Water Management }}(\mathrm{W})$ & \multicolumn{4}{|c|}{$152.849 * *$} \\
\hline$F_{\text {dose }}(\mathrm{D})$ & \multicolumn{4}{|c|}{$4135.794^{* *}$} \\
\hline$F(W) \times(D)$ & \multicolumn{4}{|c|}{136.388} \\
\hline $\mathrm{CV}(\%)$ & \multicolumn{4}{|c|}{3.7} \\
\hline
\end{tabular}

Means followed by same letter in the column and capital on the line, do not differ by Tukey test ( $>>0.05)$. $* *$ significant value for the test " $F$ " ( $p \leq 0.01)$.

stress (-1.5 MPa of water management), it was observed an average reduction of $10 \%$ (application of the herbicides sethoxydim and haloxyfop-methyl) and 35\% (herbicide fluazifop-p-butyl) in phytotoxicity symptoms, and this product presented the worst result when applied to this dose amount.

Applying half the recommended dose of sethoxydim did not reduce its effectiveness in relation to other doses used in plants without water stress $(-0.03 \mathrm{MPa}$ of water management), and in plants grown in soil with minimum stress of $-1.5 \mathrm{MPa}$ the observed control was of $92 \%$, which may also be attributed to the reactions of plants to severe water restriction. In other treatments, phytotoxicity has averaged $55 \%$, except for applications with the herbicide haloxyfop-methyl, which averaged only $23.7 \%$ in plants under higher water stress.

It can be inferred, based on these results, that the weed species $D$. horizontalis is susceptible to all products used after 14 days of application at the recommended dose, and unaffected by the water conditions imposed to the plants, when it is done on plants in an early development stage.

In applications of the commercial dose to Digitaria ciliaris weed species, 15 days after emergence, the control at 28 DAA provided by the herbicide fluazifop-p-butyl was of $87.5 \%$, and by sethoxydim was of $99.0 \%$ (López Ovejero, et al., 2005), corroborating the results found herein.
Similar results were found by Vieira et al. (2010) with ametrine herbicide application at a dose of $2400 \mathrm{~g}$ a.i. ha ${ }^{-1}$, which provided an efficient control of the access of $D$. nuda, averaged at $90 \%$ after 7 DAA and $100 \%$ after 14 DAA. In a study on the herbicides efficacy, controlling the species Digitaria spp., Dias et al. (2007) found that the herbicides from the chemical groups of triazines (ametrine) and isoxazolines (isoxaflutole) also have excellent levels of control.

Figures 1, 2, and 3 show the dry masses of weeds tested in different water management strategies, with and without herbicide application at the stage of 4-6 leaves at 14DAA.

It was observed that the control plants (without application of the products), kept in $13 \%$ minimum soil moisture, presented higher dry weight. This mass decreases as the reduced amount of water, with $48 \%$ and $62 \%$ in plants grown in soil with a minimum of 10 and $8 \%$ moisture, respectively. This reduction in dry weight was probably due to reduction of leaf area, as well as the number and thickness of roots and leaves, which may explain the results with greater control in plants without water stress, due to their larger contact area with the product, opened stomata, and less thick cuticle.

With application of $100 \%$ of the recommended herbicide flluazifop-p-butyl (Figure 1), the plant dried mass reduced on average $92 \%$ in all water management strategies applied to them. With the application of $50 \%$ and $25 \%$ of the recommended dose, there was a decrease of $88 \%$ to $69 \%$ and $81 \%$ to $56 \%$ of the plants grown in soil with minimum of 13 and $10 \%$ humidity, respectively, compared with the plants without herbicides. The reduction in dry weight was lower in plants under severe water stress ( $8 \%$ soil moisture), with an average of $57 \%$ in reduced doses of herbicide, with no differences between them.

The same behavior was observed in dry mass of plants applied with reduced doses of herbicides haloxyfop-methyl (Figure 2) and sethoxydim (Figure 3). A reduction of the dry mass of plants was noted on average $90 \%$ with the implementation of the recommended dose of herbicide haloxyfop-methyl, regardless of 


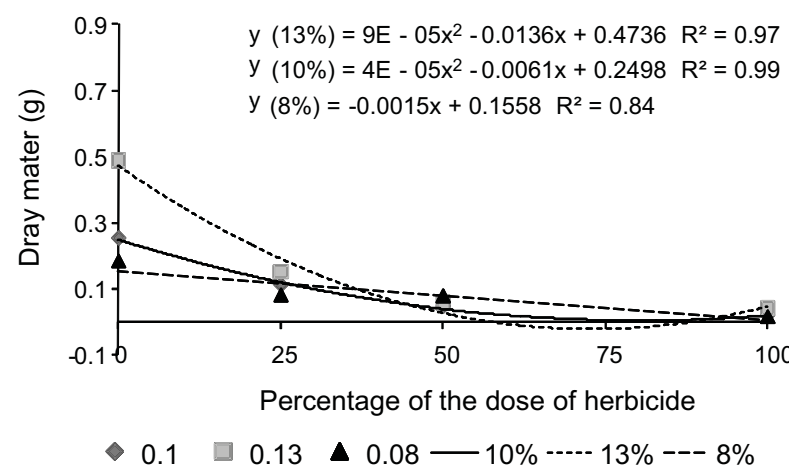

Figure 1 - Dry mass of plants of $D$. horizontalis under different water management strategies with application of the herbicide fluazifop-p-butyl, in four different doses, after 14 days on plants at 4-6 leaf stage. Botucatu-SP, 2008/2009.

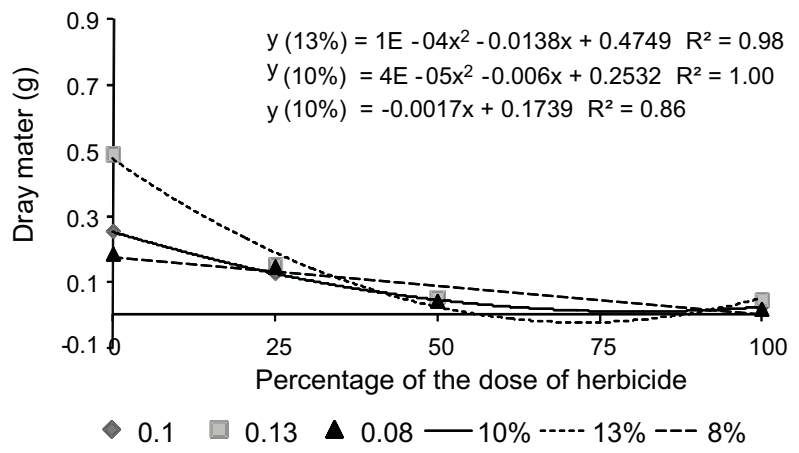

Figure 2 - Dry mass of plants of D. horizontalis under different water management strategies with application of the herbicide haloxyfop-methyl, in four different doses, after 14 days on plants at 4-6 leaf stage. Botucatu-SP, 2008/2009.

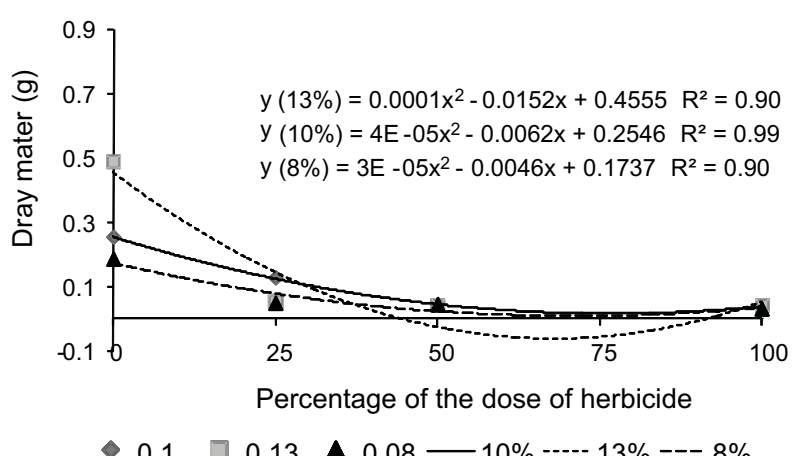

Figure 3 - Dry mass of plants of $D$. horizontalis under different water management strategies with application of the herbicide sethoxydim, in four different doses, after 14 days on plants at 4-6 leaf stage. Botucatu-SP, 2008/2009. the used water management. With the application of sethoxydim, there was influence of water management in the dry weight of plants, with a $91 \%$ reduction in plants grown without water stress (water managements at $13 \%$ ) and an average of $83 \%$ in plants grown in soils with minimum of 10 and $8 \%$ moisture.

The results of dry mass with treatment application corroborate the results of phytotoxicity, which are directly proportional; the higher the phytotoxicity, the greater the reduction in dry weight and higher efficiency of control. It is noteworthy that this increased control efficiency with herbicide application is observed in plants without water stress.

Tables 5, 6, and 7 present the control evaluations performed at 14 DAA, on the plants with herbicide application in the 2-3 tiller stage. The highest control percentages were observed in plants grown in soils with minimum stresses of -0.03 and $-0.07 \mathrm{MPa}$, reaching $100 \%$ efficiency with the implementation of the recommended herbicide haloxyfop-methyl.

By applying this same product in plants grown under severe water stress (-1.5 MPa of water management systems), the control efficiency was reduced by $21.75 \%$. On the other hand, the control provided by the herbicides sethoxydim and fluazifop-p-butyl was on average $88 \%$ and did not differ from control plants grown in soil with minimum stress of $-0.07 \mathrm{MPa}$.

Table 5 - Percentage of control plants of $D$. horizontalis at the stage of 2-3 tillers under different water managements, 14 days after application of fluazifop-p-butil. Botucatu-SP, 2008/2009

\begin{tabular}{|c|c|c|c|c|}
\hline \multirow{2}{*}{$\begin{array}{c}\text { Water management } \\
(\mathrm{MPa})\end{array}$} & \multicolumn{4}{|c|}{ Percentage of the dose of herbicide } \\
\cline { 2 - 5 } & 0 & 25 & 50 & 100 \\
\hline-0.03 & $0.00 \mathrm{aC}$ & $81.75 \mathrm{aB}$ & $95.25 \mathrm{aA}$ & $96.25 \mathrm{aA}$ \\
\hline-0.07 & $0.00 \mathrm{aB}$ & $76.25 \mathrm{aA}$ & $81.25 \mathrm{cA}$ & $82.50 \mathrm{cA}$ \\
\hline-1.5 & $0.00 \mathrm{aC}$ & $75.75 \mathrm{aB}$ & $87.50 \mathrm{bA}$ & $88.75 \mathrm{bA}$ \\
\hline $\mathrm{F}_{\text {Water Management }}(\mathrm{W})$ & \multicolumn{4}{c}{$283.131^{* *}$} \\
\hline $\mathrm{F}_{\text {dose }}(\mathrm{D})$ & \multicolumn{4}{c}{$1794.517^{* *}$} \\
\hline $\mathrm{F}(\mathrm{W}) \mathrm{x}(\mathrm{D})$ & \multicolumn{4}{|c}{$4.004^{* *}$} \\
\hline $\mathrm{CV}(\%)$ & \multicolumn{4}{c}{5.5} \\
\hline
\end{tabular}

Means followed by same letter in the column and capital on the line, do not differ by Tukey test ( $>>0.05) .{ }^{* *}$ significant value for the test " $F$ " ( $p \leq 0.01)$.

Planta Daninha, Viçosa-MG, v. 30, n. 1, p. 165-172, 2012 
Table 6 - Percentage of control plants of $D$. horizontalis at the stage of 2-3 tillers under different water managements, 14 days after application of haloxyfop-methyl. BotucatuSP, 2008/2009

\begin{tabular}{|c|c|c|c|c|}
\hline \multirow{2}{*}{$\begin{array}{c}\text { Water management } \\
(\mathrm{MPa})\end{array}$} & \multicolumn{4}{|c|}{ Percentage of the dose of herbicide } \\
\hline & 0 & 25 & 50 & 100 \\
\hline-0.03 & $0.00 \mathrm{aC}$ & $23.75 \mathrm{bB}$ & $93.75 \mathrm{aA}$ & $100.00 \mathrm{aA}$ \\
\hline-0.07 & $0.00 \mathrm{aD}$ & $25.00 \mathrm{abC}$ & $83.75 \mathrm{bB}$ & $100.00 \mathrm{aA}$ \\
\hline-1.5 & $0.00 \mathrm{aD}$ & $30.75 \mathrm{aC}$ & $68.75 \mathrm{cB}$ & $78.25 \mathrm{bA}$ \\
\hline $\mathrm{F}_{\text {Water Management }}(\mathrm{W})$ & \multicolumn{4}{|c|}{$32.961^{* *}$} \\
\hline$F_{\text {dose }}(\mathrm{D})$ & \multicolumn{4}{|c|}{$1785.633^{* *}$} \\
\hline $\mathrm{F}(\mathrm{W}) \times(\mathrm{D})$ & \multicolumn{4}{|c|}{$22.251^{* *}$} \\
\hline CV $(\%)$ & \multicolumn{4}{|c|}{7.2} \\
\hline
\end{tabular}

Means followed by same letter in the column and capital on the line, do not differ by Tukey test ( $\mathrm{p}>0.05)$. ${ }^{* *}$ significant value for the test "F" ( $\mathrm{p} \leq 0.01)$.

Table 7 - Percentage of control plants of $D$. horizontalis at the stage of 2-3 tillers under different water managements, 14 days after application of sethoxydim. Botucatu-SP, 2008/ 2009

\begin{tabular}{|c|c|c|c|c|}
\hline \multirow{2}{*}{$\begin{array}{c}\text { Water management } \\
(\mathrm{MPa})\end{array}$} & \multicolumn{4}{|c|}{ Percentage of the dose of herbicide } \\
\hline & 0 & 25 & 50 & 100 \\
\hline-0.03 & $0.00 \mathrm{aC}$ & $73.75 \mathrm{aB}$ & $87.50 \mathrm{aA}$ & $92.25 \mathrm{aA}$ \\
\hline-0.07 & $0.00 \mathrm{aC}$ & $75.00 \mathrm{aB}$ & $78.75 \mathrm{bB}$ & $88.75 \mathrm{aA}$ \\
\hline-1.5 & $0.00 \mathrm{aD}$ & $60.75 \mathrm{bB}$ & $70.00 \mathrm{cA}$ & $87.50 \mathrm{aA}$ \\
\hline $\mathrm{F}_{\text {Water Management }}(\mathrm{W})$ & \multicolumn{4}{|c|}{$33.102 * *$} \\
\hline$F_{\text {dose }}(D)$ & \multicolumn{4}{|c|}{$2001.789^{* *}$} \\
\hline $\mathrm{F}(\mathrm{W}) \times(\mathrm{D})$ & \multicolumn{4}{|c|}{$8.627 * *$} \\
\hline $\mathrm{CV}(\%)$ & \multicolumn{4}{|c|}{5.3} \\
\hline
\end{tabular}

Means followed by same letter in the column and capital on the line, do not differ by Tukey test ( $\mathrm{p}>0.05)$. ${ }^{* *}$ significant value for the test "F" ( $\mathrm{p} \leq 0.01)$.

There was no difference observed in the efficiency of controlling with the application of sethoxydim in commercial dose, regardless of the water management used. With the application of the herbicide fluazifop-p-butyl, the greatest control reduction was observed in plants growing in soil with minimum 10\% humidity. This fact can be explained by the high water restriction imposed on plants and their consequences - impaired development, yellowing, leaf curl, and death - masking the effect of the herbicide.

Differences in plants responses to the application of herbicides were observed when under water stress, since in this current work, the species $D$. horizontalis presented minor symptoms of intoxication with the application of the haloxyfop-methyl herbicide, while in $U$. plantaginea plants, the herbicide with minor efficiency was the sethoxydim, according to Pereira et al. (2010).

The application of $50 \%$ of the commercial dose of the fluazifop-p-butyl herbicide did not reduce weed control, regardless of the water management used. This data has also been observed in plants grown without water stress (-0.03 $\mathrm{MPa}$ of water management systems) with the use of other products. The best control percentages were observed in plants without water stress, reaching up to $95 \%$.

A control reduction was also noted, on average, of 18 and $10 \%$ in plants grown in soils with minimum stress of -0.07 and $-1.5 \mathrm{MPa}$, with the application of the sethoxydim and haloxyfop-methyl herbicides, respectively.

Phytotoxicity was not affected by the application of $1 / 4$ of the recommended dose of fluazifop-p-butyl herbicide in plants grown in soil with minimum of 10 and $8 \%$ moisture. On plants without water restriction (water managements of $-0.03 \mathrm{MPa}$ ) there was a $15 \%$ reduction compared to the treatments with application of $100 \%$ of the dose.

The largest control reduction was observed in applications of haloxyfop-methyl herbicide in plants grown in soil with minimum of $10 \%$ humidity. There were no effect differences among plants grown in soils with minimum stresses of -0.03 and $-1.5 \mathrm{MPa}$. This fact can be explained by the high water restriction imposed on the plants and their consequences, such as inferior development, yellowing, leaf curl, and death, masking the effect of the herbicide.

Given the above, it can be inferred that the effect of herbicides was higher on plants without water restriction and with applications in early development. There are reports in the literature where changes in the morphology of plants due to water restriction, such as the low density of stomata and higher amount of waxes, would be potential barriers to the penetration of herbicides (Procópio et al., 2003), and also the lower hydration of the leaves cuticle of plants that developed in drought. 
In the right conditions of soil moisture, over $90 \%$ of Avena fátua plants treated with $140.0 \mathrm{~g} \mathrm{ha}^{-1}$ of fenoxaprop-ethyl were controlled; however, less than $70 \%$ of plants in water stress were controlled (Xie et al., 1993). Researchers report the lowest leaf area as one of the responsible factors for lower efficacy of the applied product.

Figures 4, 5, and 6 present the weed dried mass subjected to different water management strategies, with and without herbicide application, in the 2-3 tiller stage at 14 DAA. Among the control plants (without herbicide use), the ones grown in a soil without water restriction, i.e. maintained the minimum potential of soil water of $-0.03 \mathrm{MPa}$ (water management at $13 \%$ ), presented the largest dry mass. As the water content in soil decreases, dry weight is also reduced. This reduction was of $38 \%$ and $76 \%$ in dry mass of the plants maintained in soil with a minimum of $10 \%$ and $8 \%$ moisture content $(-0.07$ and $-1.5 \mathrm{MPa})$, respectively, when compared to the plants masses that have not suffered water restriction.

It was observed that the different soil moisture influences on herbicide performance, reflecting the plants dry mass. In applications of the commercial dose of all herbicides, the lowest reductions in dry mass were on plants maintained in soils with a minimum of $8 \%$ moisture (water managements of $-1.5 \mathrm{MPa}$ ), averaging $69 \%$. In plants grown in soils with minimal stress of -0.03 and $-0.07 \mathrm{MPa}(13$ and $10 \%$ humidity), the reduction in dry mass,

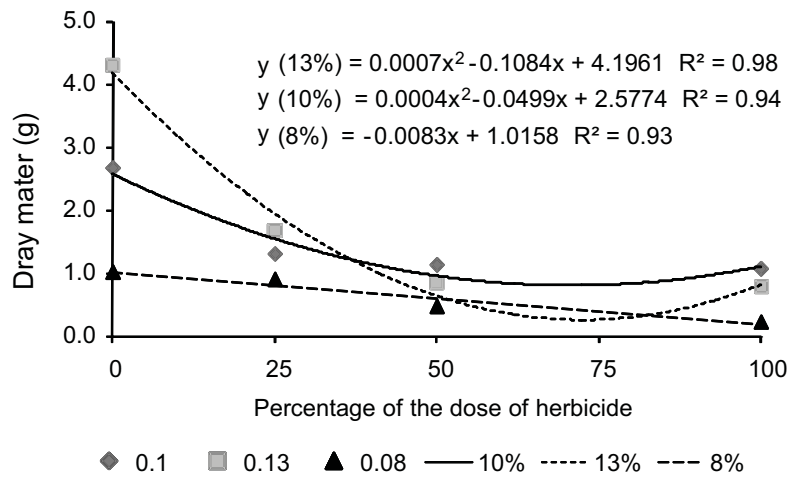

Figure 4 - Dry mass of plants of $D$. horizontalis under different water management strategies with application of the herbicide fluazifop-p-butyl, in four different doses, after 14 days on plants at the 2-3 tiller stage. Botucatu-SP, 2008/2009.

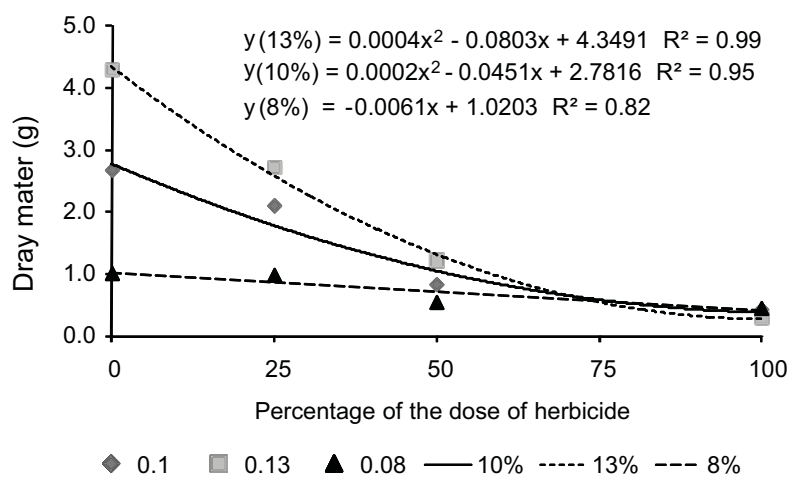

Figure 5 - Dry mass of plants of D. horizontalis under different water management strategies with application of the herbicide haloxyfop-methyl, in four different doses, after 14 days on plants at the 2-3 tiller stage. Botucatu-SP, 2008/2009.

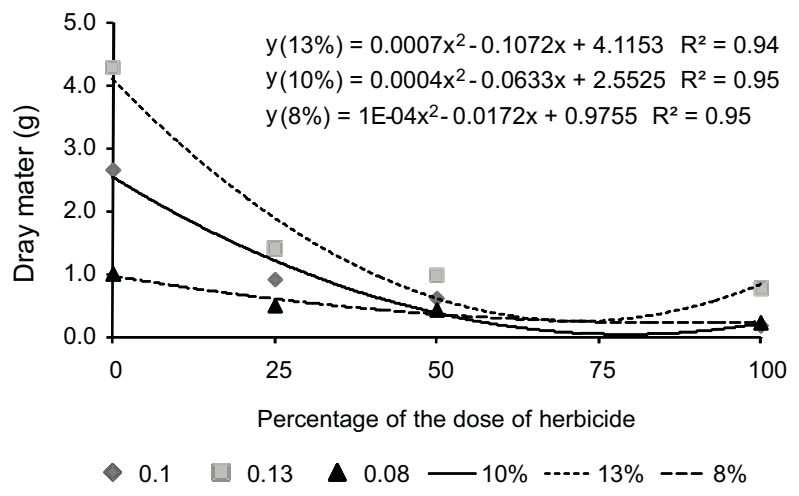

Figure 6 - Dry mass of plants of D. horizontalis under different water management strategies with application of the herbicide sethoxydim, in four different doses, after 14 days on plants at the 2-3 tiller stage. Botucatu-SP, 2008/2009.

compared with that of control plants, averaged $87 \%$. Soil moisture had a greater influence on the plants dry mass with application of haloxyfop-methyl herbicide, where the plants grown in soil without water stress (water managements at $13 \%$ ) had an average decrease of $93 \%$. In the plants exposed to soil with high water restriction (water managements at $8 \%$ ), the reduction was of only $55 \%$. In applications of reduced doses of herbicides it is noticed a gradual behavior of plants dry mass and it is inversely proportional; the lower the applied dose, the higher was the plants dry masses, a fact noticed in the applications of all studied products.

Planta Daninha, Viçosa-MG, v. 30, n. 1, p. 165-172, 2012 
Similar results were found by Zanatta et al. (2008), in which the water content in soil affected the efficiency of fomesafen herbicide on A. hybridus plants, but the level of influence varied with the applied dose. The application of the recommended herbicide provided a satisfactory control of this weed, regardless the soil moisture content, which did not occur when applied at lower doses.

Corroborating these results, Xie et al. (1993) reported that fenoxaprop-ethyl herbicide (150.0 $\mathrm{g} \mathrm{ha}^{-1}$ ) decreased by approximately $70 \%$ dry mass of non-stressed plants shoots, i.e. in adequate soil moisture, more than $90 \%$ of two strains of Avena fatua; however, the reduction in water-stressed plants was lower than $30 \%$. Researchers report the lowest leaf area as one of the responsible factors for lower efficacy of the applied product, which directly contributes to lower dry mass.

Under the conditions in which this work was done, it can be concluded that the control efficiency was excellent with the application of the recommended dose of all herbicides in the early stages of development (4-6 leaves) of plants $D$. horizontalis, regardless the applied water management. In late applications (2-3 tiller stage) the water management strategies influenced the efficiency of these herbicides on the plants, and those grown under water stress showed less phytotoxicity. Haloxyfop-methyl herbicide had the best control for late application on plants exposed to water managements -0.03 and $-0.07 \mathrm{MPa}$ of soil water stress. The dry mass accumulation in plants of $D$. horizontalis grown in soil with minimum stress of $-1.5 \mathrm{MPa}$ was less influenced with the application of different herbicides.

\section{LITERATURE CITED}

BORGHI, E. et al. Influência da distribuição espacial do milho e da Brachiaria brizantha consorciados sobre a população de plantas daninhas em sistema plantio direto na palha. Planta Daninha, v. 26, n. 3, p. 559-568, .2008.

DIAS, A. C. R. et al. Problemática da ocorrência de diferentes espécies de capimcolchão (digitaria spp.) na cultura da canade-açúcar. Planta Daninha, v. 25, n. 2, p. 489-499, 2007.

KLAR, A. E. Evapotranspiração. In: KLAR, A. E. A água no sistema solo-planta-atmosfera. 2.ed. São Paulo: Nobel, 1984. 408 p.

Planta Daninha, Viçosa-MG, v. 30, n. 1, p. 165-172, 2012
KOGAN, M.; BAYER, D. E. Herbicide uptake as influenced by plant water stress. Pestic. Biochem. Physiol., v. 56, n. 1, p. 174-183, 1996.

LEVENE, B. C.; OWEN, M. D. K. Effect of moisture stress and leaf age on bentazon absorption in common cocklebur (Xanthium strumarium) and velvetleaf (Abutilon theophrasti). Weed Sci., v. 43, n. 1, p. 7-12, 1995.

LOPEZ-OVEJERO, R. F. et al. Resistance of crab-grass (Digitaria ciliaris) populations to Acetyl-Co-A Carboxylaseinhibiting herbicides. Planta Daninha, v. 23, n. 3, p. 543-549, 2005.

MUNIZ, F. R. et al. Qualidade fisiológica de sementes de milho, feijão, soja e alface na presença de extrato de tiririca. R. Bras. Sementes, v. 29, n. 2, p. 195-204, 2007.

PEREGOY, R. S. et al. Moisture stress effects on the absorption, translocation, and metabolism of haloxyfop in johnsongrass (Sorghum halepense) and large crabgrass (Digitaria sanguinalis). Weed Sci., v. 38, n. 4/5, p. 331-337, 1990.

PEREIRA, M. R. R. et al. Efeito de herbicidas sobre plantas de Brachiaria plantaginea submetidas a estresse hídrico. Planta Daninha, v. 28, n. 5, p. 1047-1058, 2010.

PITELLI, R. A. Interferência das plantas daninhas nas culturas agrícolas. Inf. Agropec., v. 11, n. 129, p. 16-27, 1985.

SOCIEDADE BRASILEIRA DA CIÊNCIA DAS PLANTAS DANINHAS - SBCPD. Procedimentos para instalação, avaliação e analise de experimentos com herbicidas. Londrina: 1995. $42 \mathrm{p}$.

TEJEDA-SARTORIUS, O.; RODRIGUEZ-GONZALEZ, M. T. Inhibidores de germinación y crecimiento de maleza y hortalizas, en residuos de amaranto (Amaranthus hypochondriacus L.). Agrociencia, v. 42, n. 4, p. 415-423, 2008.

VICTORIA FILHO, R. Controle químico de plantas daninhas. In: VICTORIA FILHO, R. Controle integrado de plantas daninhas. São Paulo: CREA, 1985. p. 77-102.

VIEIRA, V. C. et. al. Molecular characterization of accessions of crabgrass (Digitaria nuda) and response to ametryn. Acta Sci., v. 32, n. 2, p. 255-261, 2010.

XIE, H. S.; HSIAO, A. I.; QUICK, W. A. Influence of water deficit on the phytotoxicity of imazethabens and fenoxaprop among five wild oat populations. Environ. Exper. Bot., v. 33, n. 5, p. 283-291, 1993.

ZANATTA, J. F. et. al. Teores de água no solo e eficácia do herbicida fomesafen no controle de Amaranthus hybridus.

Planta Daninha, v. 26, n. 1, p. 143-155, 2008. 